\title{
Bondages of the Protagonist Philip Carey in Maugham's of Human Bondage and His Long Pilgrimage towards Freedom
}

\author{
Xiaohong Ji \\ School of Foreign Language \\ Tianjin University of Science \& Technology \\ Tianjin, China
}

\begin{abstract}
The strength of W. Somerset Maugham's of Human Bondage mainly lies in its themes pursued with thoroughness and intensity, in its honesty and sincerity of feeling. The protagonist Philip's experiences is a typical representation of one who suffers from human bondages and struggles for freedom, and eventually finds truth and meaning in the chaotic life. In this novel, Maugham expressed more strongly the central concern of his writing: the importance of the physical, intellectual and spiritual freedom of the individual. The novel concerns with varieties of personal bondage. Through Philip's travail, we see he suffers from the bondage of passion, of religious belief and of emotional dilemmas, etc. Philip gradually frees himself from the bondages of religion, passion, class-prejudice, art, ambition, economic dependence, and the natural human desire to discover meaning and order in the universe. The revelation of life philosophy through his pilgrimage gives the enlightenment: one can overcome his weak points and surpass human bondages by exerting his will and reason.
\end{abstract}

Keywords-Of Human Bondage; spiritual pilgrimage; style; freedom

\section{INTRODUCTION}

Of Human Bondage is one of the masterpieces of the 20th century literature. It marks a turn in W. Somerset Maugham's career as a writer. It is his most significant, and emotionally and intellectually most demanding novel. "It is the most complete statement of the importance of physical and spiritual liberty."1

The strength of the novel mainly lies in its widely interesting theme pursued with devastating thoroughness and intensity: During Philip's long pilgrimage towards freedom, he undergoes the agonies of physical disfigurement, boarding school miseries, loss of faith, sexual initiation, arduous years of training to be a doctor and a desperate struggle to bring ideal into some kind of relationship with reality in sexual love. The life of Philip is full of ambiguity, paradoxes. This article mainly analyzes the three different aspects of bondages Philip suffers in the course of his growing up into maturity and the solution-put meaning in

Robert Lorin Calder, W. Somerset Maugham and the Quest for Freedom. Westminster: William Heinemann Ltd, 1972, p.129. life. Following the incidents in his life, there are revelations of Philip's spiritual struggles, doubts, search for truth and meaning, disillusions, and final attainment of a philosophy of life that releases him from the most galling shackles of his human bondage. Philip's pilgrimage towards freedom is not one from obscurity to eminence, but a pilgrimage from illusion to reality, from human bondage to freedom of spirit. Liberated from the bondage of passion, money, and religious belief, etc., Philip is his own master at last.

The language used in "Of Human Bondage" is the typical representation of Maugham's style of "economy, lucidity, and euphony." The words and sentences are characterized by simplicity and concise. However, the novel is not a simple one-for it is full of philosophy, ideas; for its use of symbol, satire and other rhetoric devices; for the rich characterization and the complete picturization of life, etc. "Of Human Bondage" is a semi-autobiography. Much of the material for the novel is drawn from Maugham's life experience. It is used to "free him from the disturbing past". Finding some parallels between Philip the protagonist, and Maugham, the writer, we can see Maugham, basing his work directly on his experience and observation has "put his life into the novel".

\section{THE THEME OF “BONDAGE” ON THREE ASPECTS AND THE SEARCH FOR FREEDOM}

Almost all of Somerset Maugham's writings deal, in one way or another, with the individual's attempt to assert his freedom from "human bondage". In the novel Of Human Bondage, Maugham expressed more strongly than in any of his other works the central concern of his writing: the importance of the physical, intellectual and spiritual freedom of the individual. One critic has called the central theme of Of Human Bondage is "Philip's quest for 'a philosophy that will free him from bondage-intellectual and emotionaland enable him to meet life with equanimity, courage and humor'." ${ }^{2}$ Because it is the most direct, thorough, and personal of his works, Of Human Bondage is generally considered to be his masterpiece and its hero, Philip Garey, to be a thinly disguised portrait of the author

Richard A. Cordell, Somerset Maugham: A Biographical and Critical Study. Bloomington: Indiana University Pr., 1961, pp. 96-97. 
Maugham took the title of his novel from the fourth part of Ethics, "Of Human Bondage or the strength of the Emotions" by Spinoza (1632-1677). He was impressed by Spinoza's assertion that we are in bondage in so far as what happens to us is determined by internal flaws and external circumstances, and that we are free in as much as we are self-determined. The novel concerns with varieties of personal bondage. Through Philip's travail, we see he suffers from the bondage of passion, of religious belief and of emotional dilemmas, etc. Philip gradually frees himself from the bondages of religion, passion, class-prejudice, art, ambition, economic dependence, and the natural human desire to discover meaning and order in the universe. By the end of the book he has achieved a measure of emotional balance and detachment.

\section{A. Bondage of Passion}

The novel mainly concerns Philip's quest for a philosophy of life, a meaning to life, a freedom from human bondage, especially bondage to passion. It should take the title from Spinoza's Ethics. ".......he was attracted to Spinoza's statement that experience is only valuable when through our imagination and reason we are able to turn it into foresight, thereby shaping our future and freeing ourselves from the past; submitting to passion is human bondage, exercising reason is human liberty." ${ }^{3}$ The main sequence, from which the book derives its title, is the affair between Philip and Mildred, a harrowing account of the degrading bondage of one human being to another. Among the bondages Philip suffers, the most significant is the bondage of passion theme: a man enslaved by his passionate nature, loves hopelessly and helplessly a vulgar, calculating, heartless woman whom in his judgement and reason he abhors and finally succeeds in casting off the shackles and is freed from his intolerable humiliating bondage. "In tracing the life of a young man from childhood to maturity Maugham demonstrates the importance of truth, beauty and goodness, and, under the influence of Spinoza, reveals how reason can be subjugated by emotion.,"4

This is a constant theme in Maugham's work; the destructive power of a passion that is against all reason. In Of Human Bondage, with this theme, Maugham invents characters whom Philip observes to be in one way or another bound by passion. "Philip's helpless bondage to Mildred is the epitome of human bondage for this protagonist" ${ }^{\prime 5}$ The war between the flesh and the spirit caught upon to the greater conflict of bondage with freedom. Although Philip is sexually attracted to Mildred, it is his enslaving obsession, his desire to possess her utterly. That is emphasized again and again throughout the novel.

Here, the author describes Philip's human bondage to an evil waitress, Mildred. The protagonist, Philip, a medical student, meets Mildred, a waitress in the A.B.C tea shop

Forrest D. Burt, W. Somerset Maugham. Boston: Twayne Publishers, 1986, p.35.

$4 \quad$ Leonard S. Klein, Encyclopedia of World Literature in the 20th Century. $2^{\text {nd }}$ ed., vol.3. New York: Frederick Ungar Publishing Co.,p. 245

Forrest D. Burt, W. Somerset Maugham. Boston: Twayne

Publishers, 1986, p.35.
Philip and other medical student at St. Luke's hospital often frequent. At first he is disinterested, thinks her unattractive and only speaks to her to try and help out his friend Dunsford who is very shy with women. When he is rebuffed, Philip is angered. But he returns to the tearoom and he begins to think about Mildred. From here, we enter the mainstream of the story, and we can see the seesaw nature of the happy and sorrow, love and hate relationship between Philip and Mildred.

The physical description that Maugham gives of Mildred is definitely not attractive. She is flat-chested, tall and thin, with thin lips and an anemic look. But she apparently has fairly good looking features and men are attracted to her. Despite her unattractive appearance, Mildred becomes more and more the object of Philip's interest. When she first speaks to him, he is elated. He draws a picture of Mildred and gives it to her. He even worked up his courage enough to ask her to a play. Her indifferent acceptance will be repeated many times during their relationship: "I don't mind." And after the evening out she continues to react in the same cold manner. The coldness continues through the early days of their relationship. He knew at the early stage that he ought not to pursue the relationship and that he would never make any impression on her. He was consumed by his passion for Mildred as by a fever. He needed her, he wanted her, he could not live away from her; and he was not happy with her. Here we run into the ambivalence that runs through the whole book. Philip, for the first time, falls in love ,desperately and hopelessly, with a woman who cares not a whit for him except possibly for what little he is able to give her monetarily. She treats him in the worst abominable manner, but Philip keeps coming back for more and more abuse. He is objective enough at times to realize that he is only making a fool of himself, but objective thinking has no place in the passion he feels. He soon realizes how helpless he has become: "He wanted passionately to get rid of the love that obsessed him: it was degrading and hateful." Philip is unhappy and humiliated at his own feeling, and he thinks that he must prevent himself from thinking of her and in a little while the anguish he suffered must grow less, but he can't stay away from her. He knows she is seeing the German, Miller by name and he is consumed by jealousy. His studies are neglected, but he is so obsessed by Mildred that he cannot concentrate on them. For a while he manages to stay away from the teashop, but after he fails his first examination in biology he can no longer restrain himself and returns. He is again humbled but when she consents to go out with him he is overjoyed. When she allows him to kiss her, his joy knows no bounds. They now dine together once or twice a week and he gives her presents that he can ill afford. But they quarrel, because of her indifference and because of his passion, and each time they make up it is only because Mildred tolerates it.

By the end of chapter LXII, Philip is thoroughly hooked. He has done everything to try and win her, even for a night. He has appealed to her sympathy, mentioning his club-foot, a humiliation he has never subjected himself to before; he has offered to kiss the ground she walks on; he has offered her a trip to Paris he cannot afford. Finally, although he knows it is 
folly, he asks her to marry him, but after she questions him on his finances she coolly refuses him. Philip is now in the clutches of a scheming, calculating heartless woman, who will use him only for what she can get out of him. At this stage, Mildred is completely indifferent and would let Philip go at any time he wishes. But the shackles are made by himself, though he becomes increasingly aware of his bondage to Mildred. Why he puts up with the abuse he receives from this slut? Maugham's answer is the one contained in the title. What makes a person a slave?passion.

Throughout the book, there is the ambivalence, the love and the hate that Maugham sees in love, we can see through the ambivalent emotions of Philip Carey, drawn to and yet repelled by the love object, fascinated and at times even enjoys the experience. He loves her madly, senselessly, but at the same time he wants to hurt her for the suffering she has caused him. And Maugham indicates that this is impossible, for you can only be hurt if you love.

As things go on, though there is no indication that she is returning her passion, she begins to show some sign of affection. Philip is delighted, then quite suddenly she tells him that she is going to marry Miller, the German. Philip is stunned and saddened and decides that he will see no more of her. He begins to feel like a patient recovering from a bad illness. At this time, he meets Norah Nesbit, a cheerful, gay, and witty woman who loves Philip heartily. They spent a good time together for a while and with her encourage, he makes up for his classes and gets on well with his studies. Here, we are led to believe that he has shaken off the Mildred shackles; Maugham tells us that his work is going easily and he is studying hard to make up for the two exams he had flunked. This episode might be called the first emancipation of Philip.

Philip returns home one day to find that Mildred is waiting for him. Once again, the passion and love that he had thought he no longer had, returns. Mildred was never married to Miller and when he found she was pregnant, he deserts her. Philip loves her more than ever, for now he feels sorry for her, he gives her money and finds her lodgings and arranges for her to have the baby in a nursing home. In the meantime, he breaks with Norah, although in the beginning he tried to maintain a friendly relationship. But in the end he is cruel to her and Norah is heart- broken. Philip is completely wrapped up in Mildred, and although he is shocked to find that she neither wants to have the baby nor to take care of it after its birth, he is the one who pays for everything and looks after the details. Mildred has a baby girl without any complications. Philip manages to send her to the seashore for a couple of weeks and then they are to go to Paris together.

The brief emancipation is over and Philip is hooked again. This time it is even worse, for now he is not only senselessly in love with her, but he feels sorry for her and therefore wants to do things for her. He knows he has never been in love with Norah and once Mildred has again entered his life he has no room in it for anyone else.
When Mildred told Philip the sad story about her "marriage" to Miller and she said she wished she had married Philip, she is not indicating any love for him, but simply that she had played the wrong card. But Philip is pleased at the remark. That shows how far gone he is. Here, he is sowing the seeds of his own destruction emotionally and financially because it is evident that he is living far beyond his means.

Mildred, who is afraid of having the baby, clings emotionally to Philip, although she is not giving him anything. Philip is her crutch, but she gives nothing in return, and takes his money and his kindness as her normal due. She has no desire to have the baby, and indicates that she wishes it would be still-born. That is another indication of the shallowness and selfishness of her character. Philip is shocked by her attitude but he is so consumed with love that he can only think of how wonderful it is that she is going to have a child. Maugham is portraying a man in the throes of self-sacrifice and Maugham here hints that this is a most dangerous emotional situation.

From Chapter LXIII through LXXVIII, Philip reaches the lowest depths of humiliation in his dealings with Mildred. This is the nadir of his self-torture, the inability to escape from the obsession that has possessed him for so long. Philip is looking after Mildred and her baby by Miller, and without this help she would be helpless. But she takes the attention as her due, and her only concession is to agree that she will go to Paris with Philip, something she would like to do in any case, and the physical favor she will do Philip is in her mind simply that, a full payment for services received.

When Mildred returns to London, there are but 6 days to go before the Paris trip. Philip is very happy, and in his happiness, he decides to share it with Griffiths. The three of them have dinner together, and the result is that the handsome and charming Griffiths and Mildred develop a passion for each other. Philip is furious, but he is so immersed in self-torture that he even offers to pay the money so that Griffiths and Mildred can spend a weekend together, if she will promise to return to him afterward. Mildred says she will and torn as he is by jealousy, Philip gives her the money. Mildred takes his money and leaves with Griffiths for Oxford. This is, in a sense, a turning point in the book. Philip is still in love, still consumed with jealousy, still longing for any little favor, but this is the lowest point he can reach. He has paid out money that he can ill afford so as to make it possible for the woman he loves desperately to have an affair with a man he considered his friend. The flagellation is almost unendurable and Philip even contemplates suicide. Mildred never does return and when Philip goes to her lodging day after day, he finally hears that he has taken her things and moves away, disappearing into the vast London scene. Philip returns to Blackstable for the holidays. He still thinks of her all the time, and while there, he does some soul-searching. Here his past experiences in human relations make him begin to look at things more rationally. He realizes that physical love is completely irrational, and in trying to make Mildred love him he had been attempting the impossible. 
"He did not know what it was that passed from a man to a woman, from a woman to a man, and made one of them a slave, it was convenient to call it the sexual instinct, but if it was more than that he did not understand why it should occasion so vehement an attraction to one person rather than another"

Philip therefore becomes increasingly aware of his bondage to Mildred. And Maugham provides the parallel bondage of Mildred to Griffiths. Even though Philip is unable to exercise reason about his own bondage, he is about to understand Mildred's, He even says that if one is in love with somebody he can't help it. He will just bear it the best he can. He sees more clearly and rationally the parallel between his situation and that of Mildred.

Nevertheless, Philip is beginning to understand, the malady is still there, but the crisis has been passed. The convalescence will be painful, and the prognosis is still not completely positive, but the second emancipation is nearing.

In the final stages of Philip's bondage he comes to conclusions about the meaning of life and relationships. After Mildred leaves with Griffiths, Philip does not see her again for some time. One evening as Philip is returning from dinner at the Athelnys on the street he runs into Mildred again, "His heart stood still. He saw Mildred. He had not thought of her for weeks..... his heart beating excitedly. He followed her. He did not wish to speak to her, but he wondered where he was going at that hour; he wanted to get a look at her face." ${ }^{, 7}$ Of course he soon learns that she has taken up prostitution. Philip talks to her, learns that the baby is being taken care of, that she must walk the street to survive. While he is disgusted and shocked, he feels a great pity for her. He wants to help. He wants to take care of her. He suggests that if she will give up the life she can come and live in his apartment and take over the simple duties he has been hiring a woman to do, Mildred and her little girl move into Philip's spare room, and Philip is happy that he is about to do something for Mildred, but his old passion is gone. Mildred is unable to understand this, now she is not only willing but anxious to give herself to him, for the physical is the only relationship with a man that Mildred understands. Philip is fond of the baby, and for her sake, and for the love he once had for Mildred, is willing to support them, but that is all. Philip spends pleasant days taking care of them. The end of these days comes when Philip after prolonged suffering and pain, realizes that he can exercise reason and there-by free himself of the passion that bound him. One night Mildred tries her utmost to seduce Philip, but he is disgusted and shakes her off.

"I do love you, Philip," she said.

"Don't talk damned rot..."

"It isn't, it's true..." The Continental Book Company AB, 1947, p.107.

W. Somerset Maugham, Of Human Bondage, vol. II.London: The Continental Book Company AB, 1947, p.199.
"I suppose it's because I love you too much I wore the passion out."

Enraged, Mildred calls Philip every vile name she can think of and ends with the epithet she knows will hurt him the most: "Cripple!" and then destroys his furniture and other few possessions and left. When Philip is returned, he is amazed at the damage, and while he feels a sense of material loss, is glad to be finally rid of Mildred.

This is the next to last act in the story of Philip and Mildred. Mildred is quite naturally puzzled at Philip's new attitude toward her. It is obvious that while Mildred does not really love Philip no longer desires her physically, when in the past he would have done anything to possess her, is incredible to Mildred. Formerly she had had no difficulties in handling Philip under any circumstances, and now that she is willing to give him what he so desperately wanted before. She is willing now to debase herself to get what she could have had before with a snap of her fingers. She can't understand why he will not take her. This makes her furious. Mildred's act of vandalism adds nothing to the story, but only emphasizes the low character of Mildred. The weird relationship with Mildred eventually eats up the remainder of Philip's small fortune of 12 hundred pounds. Finally, penniless and destitute, sleeping on park benches for days, he is compelled to enter a London shop as a clerk.....

For Philip, he is emotionally rid of her now, but being a decent person, he cannot be insensible to Mildred's plight, but his love for Mildred is now dead, and he can look only on the obsession he suffered from as a sort of disease from which he has now been cured. The intensity is loathing. After the years of emotional torture when he would have been deeply hurt, he is drained of any emotion toward her. He no longer cares. Even after viewing the wreckage of his few possessions, Philip "did not think of with wrath, but with an overwhelming sense of boredom" 9 This is the end of whatever remained of Philip's emotional bondage to Mildred. The torment of Philip's spirit is lifted. Anyway, Philip has gone through the emotional mill, and he is now free.

One day he finds a letter from Mildred saying she is in trouble and asking him to come and see her. At first he has no intention of doing so, but next day he changes his mind and looks her up. His ambivalent feeling has for her is again evident. At first he cares not at all about Mildred's troubles, but he then begins to worry. He can never rid himself of her completely; he has been scarred too deeply. Mildred now is staying in a shabby house in a sordid district. She tells him that there is something wrong with her. Philip examines her and finds she has syphilis. He prescribes some medicine for her. He tells her she must give up what she is doing, but discovers shortly that she is continuing as a street walker. Philip pleads in vain and finally he says to himself: "I can't do anything more." He never sees Mildred again.

\footnotetext{
8 W. Somerset Maugham, Of Human Bondage, vol. II. London The Continental Book Company AB, 1947, p.257.

W. Somerset Maugham, Of Human Bondage, vol. II. London: The Continental Book Company AB, 1947, p.264.
} 
The once financially independent Philip who could give Mildred little luxuries is now able to give her only a prescription and advice she will not take. But even this is something, and as usual, it is Philip who is doing the giving.

Mildred tells Philip that now he has had his revenge, he gets no satisfaction. Revenge is a cheap emotion, Maugham indicates, and Philip is above it. What is more, Philip has gone through enough sorrow himself, and is reaching his majority.

Mildred is a rather pitiful character now, and Maugham treats her compassionately. Perhaps it was inevitable from the start that she would end up a diseased prostitute, she is in the gutter, and Maugham treats the beaten kindly.

The final parting is, in many ways, a rather poignant one. Mildred, once so arrogant, is reduced to nothing. Philip, while he has his own troubles, is now a man. The contrast is tragic. And now the door is closed. "That was the end. He did not see her again." "Philip's bondage is over at long last.

The trail and tribulations Philip has endured have now finally brought him to manhood, and he is able to look about him and view things objectively. Philip is emotionally free of his obsession for Mildred, and while Maugham mentions that Philip will never be completely rid of her in his mind, he sees the relationship with her now only as a horrible period in his life that is forever behind him. In any event, the affair with Mildred has two lasting effects: Philip gains control of his passion, and, at the same time, comes to understand the limits of rationality in the face of ungovernable emotions.

From reading and discussion, we can find that in Of Human Bondage, Maugham mainly portrays the incompatible relationship between men and women. The major part of the book deals with that between Philip and Mildred. In the novel Maugham carefully prepares the reader $\mathrm{s}$ for Philip's bondage of passion, principally through Philip's relationship with Miss Wilkinson and Fanny Price and the bondage of passion that these individuals have to Philip. There is incompatibility in their relationship - their caring more for him and being bound by passion to him while he remains more detached and aloof - the reverse of the relationship between Philip and Mildred. These relationships foreshadow Philip's subsequent bondage to Mildred. Later in the novel, the character of Ruth Chalice also anticipates Mildred, who is equally free with her affections, and to whom Philip will have a hopeless bondage of passion. That is to say, Maugham's treatment of the relationship between men and women in the earlier chapters has already made preparation for Philip-Mildred relationship. In each he gives considerable attention to the imbalance in a relationship: Love is always on-sided. It is the one who cares the most who is ultimately the one victimized.

Philip's relationship with Sally is significant for the novel. The daughter of Mr. Athelney, a friend met while working, Sally is the oldest daughter of a large family. She falls into

10 W. Somerset Maugham, Of Human Bondage, vol. II. London: The Continental Book Company AB, 1947, p.359. the category of "the mother figure"11 in Maugham's writing. She expects little of himself, loves him and is sensitive to his needs. Their relationship develops quite naturally during Philip's frequent visits to the Athelney home. There is calmness about this relationship that contrasts sharply with his tense relationship with Mildred. Following an affair with Philip, Sally fears that she is pregnant. Then he "despised himself, all he had aimed at so long within reach at last, and now his inconceivable stupidity had erected this new obstacle." ${ }^{\prime 2}$ Like Maugham, Philip longed to travel to have the freedom that comes with realizing one's dreams: to go to Spain," the land of his heart... to be imbued with its spirit, its romance and color and history and grandeur. ${ }^{13}$

And now "this thing had come." He reasoned (now free from the bondage of passion) that it would be "madness to allow such an accident to disturb the whole pattern of his life... He would do what he could for Sally; he could afford to give her a sufficient sum of money. A strong man would never allow himself to be turned from his purpose. Yet he simply could not. He knew himself.,"14

When Philip is freed from the anxiety of Sally's possible pregnancy, he suddenly feels there is no satisfaction in the freedom. He realizes what he really wants is love and a family life. He discovers that he can put, not find meaning in life, can surrender to happiness and accept defeat of his selfish desire to travel and seek adventure. Philip proposes to Sally and she accepts as the book ends. Here, at last, Maugham strikes a balance. For the first time Philip is loved and the end returns the love. All other emotional episodes in Philip's life have been one-sided. Philip and Sally will marry and go to live in the country happily ever after. It is a pleasant ending to the story of one man's travail.

With the victim of passion and his own reason, Philip gives pattern and meaning to a life that has no intrinsic goodness or purpose.

\section{B. Bondage of Money}

"Philip is used to voice two of Maugham's chief preoccupations: that money is the 6th sense that enables people to enjoy the other five; and that art is meant to grace, rather than absorb a person's life"15

There is a line which repeatedly appears in this novel: Money is like a sixth sense without which you can't make a complete use of other five. Without an adequate income half the possibilities of life are shut off......

This passage taken from Of Human Bondage is the most truthful presentation of Philip's inner thoughts. It reveals

\footnotetext{
11 Forrest D. Burt, W. Somerset Maugham, Boston: Twayne Publishers, 1986, p.118.

12 W. Somerset Maugham, Of Human Bondage, vol. II. London: The Continental Book Company AB, 1947, p.450.

13 W. Somerset Maugham, Of Human Bondage, vol. II. London: The Continental Book Company AB, 1947, p.451.

14 W. Somerset Maugham, Of Human Bondage, vol. II. London: The Continental Book Company AB, 1947, p.453.

15 Paul Kuch, York Notes: Somerset Maugham Of Human Bondage. Harlow: Longman; York Press, 1982, p.57.
} 
what importance Philip attaches to money. Tracing back Philip's some 30 years life experience in this book, his attitude towards money always exhibit like this. There are not only the shackles of passion enslaving Philip, but also that of money.

Although Philip's father was a surgeon in good standing, he left very little when he died; what's more, Philip's mother was not good at managing money, so after her death, Philip only inherited from his mother 2,000 pounds, and it is barely enough to see him through until he masters a profession, which, as a gentleman in England at that time, is the only course left to him. He is then sent to live with his uncle and aunt at Blackstable. From then on, he will no longer have the luxuries he had ever had. There lies a bleak world ahead for him. So, even in his childhood, he began to sense the importance of money. But Philip Carey is not an orphan in the slum of London. He is not starving, nor is he beaten. He is not an Oliver Twist, but he is a young gentleman in somewhat straitened circumstances and will have to live in a different manner in the future. The little boy is entering a very lonely life among adults, who, while they do not dislike him, neither want him nor really love him-even though they may wish to.

He went through his boyhood, attending the preparatory school, then the King's school, after that he left for Heidelberg to study for a year. During this period, in addition to the suffering from the sense of inferiority caused by his clubfoot, the economic problem is also an obsession that never ceases to worry him. He lives a thrifty life and there is no spare money for luxury. After schooling, he goes to a chartered accountant's firm to learn the business for 5years. In the British office, while Philip is called on to do the same kind of menial work that the other clerks do, actually he and the son of a wealthy brewer by the name of Watson, another articled clerk, are the only ones that can never hope to rise above what they are at present. Even Goodworthy, the managing clerk, is destined forever to remain such. Here again, he runs into the difference between gentlemen and ordinary men in Victorian England. $\mathrm{He}$ senses more consciously the importance of money. Because Philip was born a gentleman and received a gentleman's education and because he is able to pay the sum of 300 pounds to the firm for his period of apprenticeship, the road is open to him to become a chartered accountant, whereas however brilliant one or another of the other clerks maybe, they are destined to stay just that. Waston, the brewer's son, is not exactly a gentleman, nor is the head of a company, Mr. Calter. Both are depicted as a new breed that is appearing. Money has made them gentleman, not birth.

Then he finds the work is uninteresting and he has no talent for it. He resolves to get away from the life, and the feeling is reinforced when he has a chance to spend a week in Paris. While nothing special happens he is enchanted with the France capital. He finally decides he goes to Paris and study art. He knows that if he leaves at the end of the year, he will salvage half the sum that has been paid out for his apprenticeship. When he returns to Blackstable, he broaches the scheme to the Vicar, who will have nothing to do with it and refuses to give Philip the money he need to go to Paris.
However, unexpectedly, his aunt, this time, repels her husband. Showing great love for him, she exhausts her savings to give him the money.

The Parisian life agrees with Philip, but it costs him more than he had expected. He also witnesses Fanny Price, Philip's fellow student in art classes, commits suicide, a victim of hopelessness and abject poverty.

Later he decided to follow his father's profession. $\mathrm{He}$ gave up painting and began to study medicine. During this period he meets Mildred, the waitress and fall in love with her madly and irrationally. He asks her to marry him, but after she questions him on his finances, he coolly refuses him. He does everything to try and win her; gives her present which he can ill afford; even offers her a trip to Paris he cannot afford. Mildred takes everything that he offered as due course. However, later, she told him she will marry Miller, the German.

When Mildred returns to him after being deserted by Miller, Philip gives her money and finds her lodgings and arranges for her to have the baby in a nursing home. He pays for everything and looks after the details. In taking up with a pregnant Mildred this time, in looking after her and her baby by Miller, Philip is divorcing himself from the happiness that he had in the brief interlude between the time he last saw her and now; he is also sowing the seeds of his own destruction financially-for he is living far beyond his means. But Mildred takes his money and his kindness as her normal due. After the birth of the baby, Philip sends Mildred to a seaside resort for a rest. She does not wish to keep the baby and wants to pay someone to look after it. Of course, all these add to the expenses of Philip.

Mildred and Griffiths, Philip's friend has developed a passion for each other. When Philip learns of the infatuation they have for each other, he attempts a break, but Mildred, for financial reasons, is not to be put off easily. She has learnt that Griffiths does not have any money at all, and she is still dependent on Philip. So she asks for the help of Philip. Philip, though burned with jealousy, offers to pay for Griffiths and Mildred to go away to Oxford for a weekend. Mildred takes his money and leaves with Griffiths for Oxford. She does not look him up after returning from Oxford, and disappears into the vast London scene. Philip returns to Blackstable for the holidays.

Afterwards, Philip returns to London and gets himself an unfurnished apartment. He became an outpatient's clerk. He again meets Cronshaw, the poet who he knew in Paris, old and dying. When Philip finds that the old poet is living in terrible circumstances, he prevails upon him to come and live with him, and Cronshaw is happy to do so. Cronshaw dies, and Philip arranges for the funeral. Philip's financial position is steadily worsening. He is spending more than he can afford; his generosity to Mildred, and unexpected expenses such as the funeral of Cronshaw, are eating into his now very meager capital. He will earn no money until he has completed his education and this is still some years away.

He runs into Mildred again. He discovers that she is now a streetwalker. While he is disgusted and shocked, he feels a 
great pity for her. He suggests that if she will give up the life she can come and live in his apartment and take over the simple duties he has been hiring a woman to do. They move in Philip's spare room. Philip is fond of the baby, and for her sake, and for the love he once had for Mildred is willing to support them. One night Mildred tries to seduce Philip, but was spurned. She became furious. She tries to destroy the few material things that Philip likes. When he returns he finds that apartment is in shambles; the furniture slashed, dishes broken, bed clothes ripped. Philip is amazed at the damage. He feels a sense of material loss. He salvages what he can from the wreckage and moves into a cheap room, convenient to the hospital. This is important, for the funds are running dangerously low.

Philip now reaches the lowest point in the fortunes. He had met at a stockbroker named Macalister, who tells him of the fortunes that could be made in stocks. Philip looks forward to a trip that will bring him in some money. But the Macalister's suggested stock deal backfires and Philip finds that, after paying off on the stock he had bought on margin, he is left with only 7 pounds. He writes to his uncle for help, but is turned down. He still hands out homilies and platitudes but not kindness or money. He is desperate and doesn't know what to do. Unable even to pay his modest rent, he takes to wandering the streets and he knows hunger for the first time in his life. He looks for employment but he has no experience, and there are many others looking for work. This is a period in Philip's life when he hits rock bottom financially. Maugham shows us poverty as it concerns Philip, a young man who has always had something even if it wasn't a great deal. Now Philip discovers what it is to be completely penniless. Because he has had no experience with such a state of affairs, he is helpless. Philip looks for a job, but we feel that he doesn't really want one. He is vaguely hoping for some miracles to happen and cannot believe that the condition he finds himself in is real. Philip is still immature and has much to learn. He has gone through the emotional mill; now he must go through the financial.

Thanks to Athelney, he manages to get a job in the shop where Athelney works. He enters into the life of a shopwalker in a linendraper's, a shop that sells cloth and women's clothes. He lives in a dormitory with the other clerks, and eats with them. It is a miserable existence compared to what he has known in the past, but at least he had a place to eat and sleep and earns a few shilling a week.

Emotionally, Philip is now free, but has been reduced to the status of a shopwalker and he sees nothing ahead for himself unless his uncle dies and leaves him enough money to continue his medical education.

Philip is anxious for his uncle to die. There is no sentiment in his emotions; he is quite bluntly ghoulish. Philip has never cared for his uncle, and when the Vicar refuses to help him, his feeling become more intense.

When Philip gets to know Mildred has syphilis, the once financially independent Philip who could give Mildred little luxuries is now able to give her only a prescription and advice.
Philip goes to see his uncle during the Christmas holidays. The old man is very ill but hangs grimly on to life. Philip is anxious for him to die, for this will make it possible for him to resume his medical education and escape from the hated shop. He even thinks of giving the Vicar an overdose of drugs, but cannot bring himself to do so. Maugham bars the soul of man, showing how desperate a person can become when frustrated.

When Philip returns for the death watch, he is only interested in how long it will be before he will come into his inheritance so he can resume again his life as a medical student. He does not care one whit about his uncle, but as he watches him die, a change comes over Philip. He is filled with pity at how meaningless a man's life can be.

After his uncle's funeral, Philip returns to London to continue his medical education .Financially, the Vicar's death again put Philip in a position where he can have small comforts. It is possible for him now to finish his medical education, and he will have a small sum left over for emergencies. Armed with a medical degree and a few pounds in reserve, the future is bright.

So, in his life, Philip has suffered from the straitened circumstances and the economic problem has always worried him until he gets inheritance from his uncle. In this sense, he is enslaved by the bondage of money. He knows consciously the importance of money, the power of money: it is vital in one's life. The following passage which comes from the mouth of Monsieur Foinet expresses candidly and vividly the author's view concerning the problem of money, and it is also a very good illustration to the bondage of money Philip has suffered: "There is nothing so degrading as the constant anxiety about one's means of livelihood. I have nothing but contempt for the people who despise money. They are hypocrites or fools. Money is like a sixth sense without which you cannot make a complete use of the other five. Without an adequate income half the possibilities of life are shut off....It exposes you to endless humiliation, it cuts your wings, it eats into your soul like a cancer. It is not wealth one asks for, but just enough to preserve one's dignity, to work unhampered, to be generous, frank, and independent. I pity with all my heart the artist, whether he writes or paints, which are entirely dependent for subsistence upon his art"16. Here contains a vivid metaphor-money is compared to "the sixth sense that enables people to enjoy the other five". That is to say, money provides one with all the enjoyment in life; without money, life is meaningless, and everything is empty. An artist is dependent on money to pursue his art because money provides one with chance; it preserves one's dignity. Maugham put these views into the mouth of Monsieur Fionet. And by the end of the novel, these views have become so firmly Philip's own, that in his final year of medicine, with the prospect of a good medical practice ahead of him, he finds it: "very comfortable to be heart free and to have enough money for his needs. He had heard people speak contemptuously of money; he wondered if they had ever

16 W. Somerset Maugham, Of Human Bondage, vol. II. London: The Continental Book Company AB, 1947, p.377. 
tried to do without it.....you needed a competency to rate it at its proper value." 17

On the other hand, although Philip has been awkward for the sake of money, he is not entirely a slave to money. There is much evidence in the novel, showing that he is kind, sensitive to others' needs, even generous. He is willing to help others though he is not better off. His generosity to Mildred, to Cronshaw, etc, is all good examples to illustrate this point. Towards the end of the novel, going through the financial mill, Philip is finally freed from the bondage of money.

\section{Bondage of Religious Belief}

In the process of Philip's maturity, he has also suffered from the "degrading bondage of christianity". He undergoes the emotional religious experiences of the normal child and adolescent under strong pressure. It took Philip a long time to shake off the shackles of his uncle's conventional morality and values.

After the death of his parents, Philip was sent to his uncle's home in the vicarage. Life there was dull, and dominated by a fixed daily and weekly colorless routine. People there are honest, God-fearing folk, content in the main, to be what they are. Philip's uncle, the vicar, is a selfcentered, selfish martinet .He attempted to bring Philip up as a gentleman and a Christian. He often takes Philip to go to the church. One Sunday when Philip is ordered by his uncle to learn a short prayer, selected for the day, and is unable to do so, he breaks out crying. He was lonely and unhappy in that environment. What's more, he suffered from the strong pressure of religion and the rigid, stale atmosphere of his uncle's family.

Philip was enrolled in the preparatory school attached to King's school at Tercanbury, an institution, designed to prepare the boys for the clergy. He spends some 3 and half years in the school. He is subjected to the usual cruelty of the other boys to a newcomer and finds it doubly difficult because of his clubfoot. With his clubfoot he is unable to become one of the crowds and remains the outsider. After a time his deformity ceases to interest the others, but Philip becomes very sensitive about it. He is unable to take part in sports, and this further sets him aside from the others. He does well in his studies, however, and is known as a bit of a grind, something which does not sit too well with his fellow student .In this growing up period, Philip is drawing more and more into himself, and life is a misery for him. At one point the school is seized with religious fervor and all the boys, including Philip become very devout. The wave of religiosity that hits the school is made to order for Philip at thistime. He reads in the New Testament that:"... whatsoever ye shall ask in prayer, believing, ye shall receive." He finds in it a hope that God will perhaps make him whole if he believes with all his soul. One holiday back at the vicarage, he has an unusual experience. When his uncle tells him that it is true that faith can remove mountains, he prays that his foot will be healed, and he is convinced that God will answer

17 W. Somerset Maugham, Of Human Bondage, vol. II. London: The Continental Book Company AB, 1947, p.408. his prayers before the Christmas holiday end. When no miracle occurs, he tells his uncle who explains that it means she "hadn't yet faith". Philip can't understand this: he thinks that no one would have believed more than he did. Finally he comes to the conclusion: "I suppose no one ever has faith enough." He begins to feel a dull resentment toward people like his uncle, the Vicar, who had told him that mountains could be moved by faith. So when God fails to heal his clubfoot, his disappointment is the first step toward his eventual loss of faith. Step by step, the little orphan is discovering he can depend on nothing but himself.

At the age of 13, Philip enters the Kings' school at Tercanbury. It is an ancient school, dating back to the days of Henry VIII: The curriculum is classic, with emphasis on the dead languages. Philip does well in school in the beginning. The headmaster, Mr. Perkins, who is interested in seeing Philip enter the ministry, takes an interest in him when Philip finally shows no inclination to try for a scholarship at Oxford, turns against him, Philip then decides he would like to leave school and go to Germany for a year. He wants to see the world, but his first try at getting away is foiled by the Vicar and the Perkins, who prevail on him to stay at the school a little longer. In the end he wins out and goes to Germany.

He spends a year studying in Heidelberg. It is there that he loses even more confidence in his childhood faith in God. Following closely upon his first experience of personal freedom, Philip has his initial taste of intellectual and spiritual emancipation. In Heidelberg he discovers a world he had never known existed. He is exhilarated by it, by the new surroundings, the new freedoms, the new acquaintances. He undergoes the first independent awakening of his mind. Philip, a boy of 18 , being influenced by those he meets, is more and more becoming a spectator of the human foibles that go on around him. Two new friends, Haywards and Weeks, introduce him to the world of ideas. Hayward becomes his mentor and gives him a thorough grounding in the great books of the day, but it is Weeks who supplies him with the one volume, Renan's "Vie de Jesus", that has the most profound effect. It liberates Philip from his unconscious acceptance of Christian dogma and gives him an exultant new sense of personal freedom. He debates with Weeks, and sees the world through other than Anglican glasses. He discovers that it is impossible to be virtuous and unbelieving: that the nature of people's belief is related largely to geography. Under the influence of two fellow lodgers, one an American and the other an Englishman, Philip comes to what for he is an exhilarating and freeing conclusion that there is no God. When he finally confesses to himself that he does not believe God, he is exultant.

"...To Philip intoxicated with the beauty of the scene, it seemed that it was the whole world which was spread before him, and he was eager to step down and enjoy it. He was free from degrading fears and free from prejudice. He could go his way without the intolerable dread of hell-fire. Suddenly he realized that he had lost also that burden of responsibility which made every action of his life a matter of urgent consequence. He could breathe more freely in a lighter air. He was responsible only to himself for the things he did. 
Freedom! He was his own master at last. From old habit, unconsciously he thanked God that he no longer believed in Him",18

\section{CONCLUSION}

The strength of Human Bondage mainly lies in its themes pursued with thoroughness and intensity, in its honesty and sincerity of feeling. The protagonist Philip's experiences is a typical representation of one who suffers from human bondages and struggles for freedom, and eventually finds truth and meaning in the chaotic life. The revelation of life philosophy through his pilgrimage gives one enlightenment: one can overcome his weak points and surpass human bondages by exerting his will and reason. This theme will be of lasting interest and great value to the world.

The style of the novel is characterized by simplicity, naturalness and clearness; however, it is not too simple-for its use of satire, symbol and other rhetorical devices, for its ideas, and its complete picturization of life. It deserves further serious critical study for more revelation of its value.

\section{REFERENCES}

[1] F.B. Huggins, Cliff Notes: Maugham's Of Human Bondage. Lincoln, Nebraska: Cliff Notes. Inc, 1963.

[2] James Vinson, Novelists and Prose Writers, Great Writers of the English Language. The Macmillan Press Ltd., 1979.

[3] Anthony Curtis and John Whitehead, W. Somerset Maugham: The Critical Heritage. Oxfordshire: Routledge, 2013.

[4] Forrest D. Bburt, W.Somerset Maugham, Boston: Twayne Publishers, 1986.

[5] W. Somerset Maugham, Of Human Bondage.Westminster, London: Peguin Books, 1988.

[6] W. Somerset Maugham. Of Human Bondage vol.I, II. London: The Continental Book Company AB, 1947.

[7] Jeffrey W. Hunter, Contemporary Literary Criticism: Criticism of the Works of Today's Novelists, Poets, Playwrights, Short Story Writers, Scriptwriters, and Other Creative Writers.Farmington Hills, Michigan: Cengage Gale, 2011.

[8] Merritt Moseley, Dictionary of Literary Biography: British Novelists 1890-1929: Modernists. Farmington Hills, Michigan: Cengage Gale, 1998.

[9] Paul Kuch and Peter Jacob Kuch, Somerset Maugham Of Human Bondage. Harlow: Longman, 1982.

[10] A Library of Literary Criticism: Modern British Literature. Martin Tucker and Rita Stein, Eds. New York : Ungar Pub Co , 1976.

[11] James P. Draper, World Literature Criticism: Supplement: 1500 to the Present. Farmington Hills, Michigan: Cengage Gale,1997.

[12] W.S. Bunnell, Brodie' Notes on Somerset Maugham's Of Human Bondage . London : Pan Books, 1977.

[13] Richard A. Cordell, Somerset Maugham: A Biographical and Critical Study. Bloomington: Indiana Univ. Pr., 1961.

[14] Anthony Curtis, Writers and Their Work: Somerset Maugham. Plymouth: Northcote House, 1982.

18 W. Somerset Maugham, Of Human Bondage, vol. II. London:

The Continental Book Company AB, 1947, p.173. 